\title{
Evaluation of quality of life of visually impaired
}

\author{
Avaliação da qualidade de vida de deficientes visuais \\ Evaluación de la calidad de vida de deficientes visuales
}

\section{Cristiana Brasil de Almeida Rebouças', Moziane Mendonça de Araújo", Fernanda Cavalcante Braga", Giselle Taveira Fernandes"II, Samira Cavalcante Costa"II}

\author{
' Universidade Federal do Ceará, Nursing Department. Fortaleza, Ceará, Brazil. \\ "Universidade Federal do Ceará, Postgraduate Program in Nursing. Fortaleza, Ceará, Brazil. \\ I' Universidade Federal do Ceará, Graduate Program in Nursing. Fortaleza, Ceará, Brazil.
}

\begin{abstract}
How to cite this article:
Rebouças CBA, Araújo MM, Braga FC, Fernandes GT, Costa SC. Evaluation of quality of life of visually impaired. Rev Bras Enferm [Internet]. 2016;69(1):64-70. DOI: http://dx.doi.org/10.1590/0034-7167.2016690110i
\end{abstract}

Submission: 04-15-2015 Approval: 09-22-2015

\begin{abstract}
Objective: to evaluate the quality of life of visually impaired using WHOQOL-100. Method: exploratory, descriptive, and quantitative study, performed between April and May 2013 with 20 visually impaired of the Blind Association of Ceará, through interviews. Results: the analysis showed that males predominated $(80 \%), 41-55$ years $(40 \%)$, students $(50 \%)$ and personal income than the minimum wage $(70 \%)$. Participants were self-rated with good quality of life $(68.75 \%)$. The facets with the highest rates were personal relationships $(74.06 \%)$, sexual activity $(66.88 \%)$ and spirituality/religion/personal beliefs $(65 \%)$. With lower rates were financial $(43.44 \%)$, physical environment: pollution/noise/traffic/climate $(46.88 \%)$, physical security and protection $(37.19 \%)$, transport $(35.63 \%)$ and medication or treatment dependency $(8.25 \%)$. Conclusion: these results reflect the importance of the nurse to perform health education actions promoting the empowerment, autonomy and guaranteed of access in society for this clientele.

Key words: Quality of Life; Visually Impaired Persons; Nursing Care; Nursing; Education of Visually Impaired Persons.
\end{abstract}

\section{RESUMO}

Objetivo: avaliar a qualidade de vida de deficientes visuais utilizando WHOQOL-100. Método: estudo exploratório, descritivo e quantitativo, realizado entre abril e maio de 2013 com 20 deficientes visuais da Associação de Cegos do Estado do Ceará, por meio de entrevista. Resultados: a análise mostrou que predominaram sexo masculino (80\%), 41 a 55 anos (40\%), estudantes $(50 \%)$ e renda pessoal de até um salário mínimo $(70 \%)$. Os participantes se autoavaliaram com boa qualidade de vida $(68,75 \%)$. As facetas com maiores índices foram relações pessoais $(74,06 \%)$, atividade sexual $(66,88 \%)$ e espiritualidade/ religião/ crenças pessoais $(65 \%)$. Com menores índices foram recursos financeiros $(43,44 \%)$, ambiente físico: poluição/ ruído/ trânsito/ clima $(46,88 \%)$, segurança física e proteção $(37,19 \%)$, transporte $(35,63 \%)$ e dependência de medicação ou de tratamentos $(8,25 \%)$. Conclusão: esses resultados refletem a importância do enfermeiro em realizar ações de educação em saúde promovendo o empoderamento, autonomia e garantia de acesso na sociedade para esta clientela.

Descritores: Qualidade de Vida; Pessoas com Deficiência Visual; Cuidados de Enfermagem; Enfermagem; Educação de Pessoas com Deficiência Visual.

\section{RESUMEN}

Objetivo: evaluar la calidad de vida de deficientes visuales usando WHOQOL-100. Método: estudio exploratorio, descriptivo y cuantitativo, realizado entre abril y mayo de 2013, con 20 deficientes visuales de la Asociación de Ciegos de Ceará, a través de entrevistas. Resultados: el análisis mostró que el sexo masculino predomina ( $80 \%), 41$ a 55 años $(40 \%)$, estudiantes $(50 \%)$ y con ingresos personales de hasta un salario mínimo (70\%). Los participantes se auto-evaluaron con buena calidad de vida $(68,75 \%)$. Las facetas con mayores tasas fueron relaciones personales $(74,06 \%)$, la actividad sexual $(66,88 \%)$ y la espiritualidad/ religión/ creencias personales $(65 \%)$. Con menores tasas fueron recursos financieros $(43,44 \%)$, ambiente físico: la contaminación/ruido/ tráfico/clima $(46,88 \%)$, la seguridad física y la protección $(37,19 \%)$, el transporte $(35,63 \%)$ y la dependencia a medicamentos o 
tratamientos $(8,25 \%)$. Conclusión: estos resultados reflejan la importancia de la enfermería para realizar acciones de educación para la salud que promueven el empoderamiento, la autonomía y la garantía de acceso en la sociedad para esta clientela.

Palabras clave: Calidad de Vida; Personas con Deficiencia Visual; Cuidados de Enfermería; Enfermería; Educación de personas con Deficiencia Visual.

\section{INTRODUCTION}

The quality of life is a concept far-reaching affected in a complex way not only for physical health but also for the psychological state, level of independence, social relationships, and environmental factors. The World Health Organization (WHO) defined the quality of life as the individual's perception of their position in life in the context of culture and value system in which they live and about their goals, expectations, standards and perceptions ${ }^{(1)}$. Thus, measuring the quality of life of an individual, regard not only to assess their state of health but also to the understanding of the patient, centered in the perception of the functioning of the various aspects of their life.

Visual impairment can be understood as an organic character impediment related to ocular diseases that affect the normal functioning of vision. This can result in the total absence of visual capacity of the individual and can occur with or without the perception of light, which may be inherited or acquired ${ }^{(2)}$.

To make an analysis of quality of life for visually impaired can result somewhat paradoxical when evaluated in a superficial way and seen from the perspective of a society called as inclusive. However, it is certain that quality of life and visual impairment are two concepts that may be widely connected, proven fact when, in a more critical vision, the thought is expanded to center on all perspectives that provide to the individual a good quality of life in front of their difficulties ${ }^{(3)}$.

The lack of research evaluating the quality of life for persons with visual impairment justifies this study. This fact generates some concern, since, according to the latest census performed by the Brazilian Institute of Geography and Statistics (IBGE) in 2010, in Brazil, more than 35 million people have some visual impairment ${ }^{(4)}$.

It should also emphasize the relevance of this research because if anyone should judge and evaluate the quality of life is good or not; it is the disabled individual. Many stigmas and affirmations are said about these people and, unfortunately, in most cases, by individuals who do not have such disabilities or are unaware of the reality faced by these individuals, limiting and often distorting the information regarding this population $^{(3)}$.

Therefore, knowledge and assessment of the quality of life of visually impaired people is important and can help to elaborate nursing interventions during the rehabilitation process to maintain or improve both health conditions such as welfare, favoring the increase in quality of life of individuals.

Based on the preceding, the study aimed to evaluate the quality of life of visually impaired using the instrument The World Health Organization Quality Of Life- WHOQOL-100.

\section{METHOD}

It is an exploratory, descriptive study with a quantitative approach, applying the WHOQOL-100 instrument (Portuguese version).

The total studied population consisted of 80 older age individuals and members of the Blind Association of Ceará (ACEC). The data were collected through interviews, between the months of April and May 2013. It was used convenience sampling, resulting in a sample of 20 visually impaired, because these were regularly participating in the association's activities. Therefore, the sample corresponded to the total number of people that it was possible to recruit in the established period.

During breaks from lessons of the Association, the disabled were invited to participate in the study. Those who assent, signed the Informed Consent (IC). The instrument was applied by the researchers individually in a private room. Each interview had lasted approximately 40 minutes. In the meantime, the sociodemographic data were collected and concerning the application of WHOQOL-100.

To avoid bias and targeting the veracity of the answers, five individuals were excluded with intellectual disabilities, because when the instrument was applied, it was perceived the limitation in understanding the questions and difficulty in answering the questions.

The WHOQOL-100 instrument, developed by a group specialized in the quality of life of the World Health Organization (WHO), consists of 100 questions and is divided into six domains, namely: Physical; Psychological; Independence Level; Social Relationship; Environment; and Spirituality/Religiosity/ Personal Beliefs. These domains are divided into 24 facets. Each facet consists of four questions. In addition to the 24 specific facets, the instrument has a 25th consisted of general questions about the quality of life ${ }^{(1)}$.

All WHOQOL-100 questions are objective, with Likert scale type answers composed of five members, ranging from 1 to 5 . The most negative response represents 1 and the most positive 5 . These extremes represent $0 \%$ and $100 \%$ respectively. There are four different types of the scale of answers, which qualify the issues within an intensity of magnitude (nothing to extremely), capacity (anything until completely), frequency (never to always) and evaluation (very dissatisfied to very satisfied/very poor up very good) ${ }^{(5)}$.

The WHOQOL-100 application results are expressed through the scores of each facet and domain. The average scores are converted to a scale from 0 to 100 . The closer to 100 , the better the quality of life ${ }^{(5)}$.

For data analysis, it was used a tool that performs calculations to analyze the quality of life by WHOQOL-100 ${ }^{(5)}$ through 
Microsoft Excel. Data were processed according to descriptive statistics and supported in the literature concerning the matter.

The study met the ethical aspects throughout its journey and was approved by the Ethics Committee of the Federal University of Ceará. All participants signed the Informed Consent (IC).

\section{RESULTS}

The socio-demographic data of respondents by gender, age, marital status, occupation, education, religion, personal and family income are shown in Table 1.

Table 1 - Socio-demographic data of the visually impaired of the Blind Association of Ceará, Fortaleza, Brazil, 2013

\begin{tabular}{|c|c|c|}
\hline Variable & $\mathbf{n}$ & $\%$ \\
\hline \multicolumn{3}{|l|}{ Sex } \\
\hline Male & 16 & 80 \\
\hline Female & 4 & 20 \\
\hline \multicolumn{3}{|l|}{ Profession } \\
\hline Student & 10 & 50 \\
\hline Massage Therapist & 3 & 15 \\
\hline Computer Technician & 2 & 10 \\
\hline Other professions * & 5 & 25 \\
\hline \multicolumn{3}{|l|}{ Personal Income (minimum wage) $* *$} \\
\hline To one & 14 & 70 \\
\hline From 1 to 2 & 6 & 30 \\
\hline \multicolumn{3}{|l|}{ Schooling } \\
\hline Incomplete primary education & 8 & 40 \\
\hline Complete primary education & 3 & 15 \\
\hline Incomplete high school & 3 & 15 \\
\hline Complete high school & 2 & 10 \\
\hline Incomplete higher education & 2 & 10 \\
\hline University graduates & 1 & 5 \\
\hline Not informed & 1 & 5 \\
\hline \multicolumn{3}{|l|}{ Marital status } \\
\hline Single & 10 & 50 \\
\hline Married & 4 & 20 \\
\hline Consensual Union & 3 & 15 \\
\hline Divorced & 3 & 15 \\
\hline \multicolumn{3}{|l|}{ Religion } \\
\hline Evangelic & 8 & 40 \\
\hline None & 7 & 35 \\
\hline Catholic & 5 & 25 \\
\hline \multicolumn{3}{|l|}{ Age (years old) } \\
\hline 41 a 55 & 8 & 40 \\
\hline 31 a 40 & 6 & 30 \\
\hline 18 a 30 & 6 & 30 \\
\hline \multicolumn{3}{|l|}{ Familiar Income (minimum wage) } \\
\hline 1 to 2 & 7 & 35 \\
\hline Over de 2 & 6 & 30 \\
\hline Not informed & 5 & 25 \\
\hline To 1 & 2 & 10 \\
\hline
\end{tabular}

Notes: *other professions: Radiology technician (1), athlete (1), warehouse assistant (1), laboratory assistant (1) and business consultant (1); ** the effective wage during the study period was $R \$ 678.00$.
As shown in the table above, there was a predominance of males $(80 \%)$, personal income till one minimum wage $(70 \%)$ and younger than 40 years $(60 \%)$. As for the profession, $50 \%$ of respondents said they were students.

Regarding the facet Quality of Life of General domain, which refers to a self-assessment of quality of life according to the respondents, they self-assessed with good quality of life $(68.75 \%)$, as shown in Figure 1.

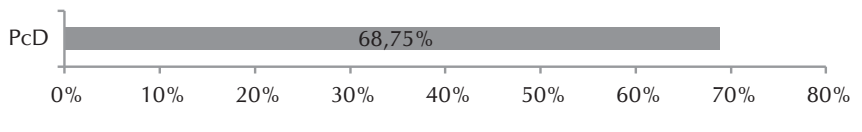

- The quality of life from the perspective of the disabled person

Figure 1 - Percentage obtained in Quality of life Facet from the perspective of the evaluated, Fortaleza, Ceará, Brazil, 2013

Figure 2 shows the scores as a percentage of the total obtained in each domain of WHOQOL-100 instrument.

\section{Domains}

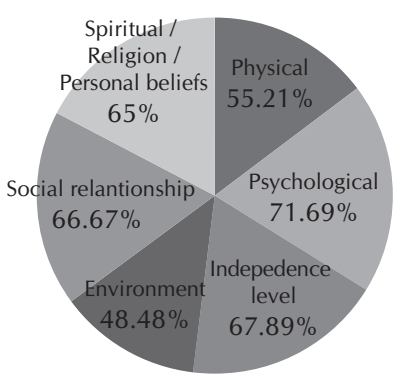

- Physical

- Psychological

- Independence level

- Environment

- Social relationship

- Spiritual / Religion / Personal beliefs

Figure 2 - Scores shown as a percentage of the total obtained for each domain, Fortaleza, Ceará, Brazil, 2013

According to the research, the domain that reached a better quality of life was the Psychological $(71.69 \%)$. The Physical domain $(55.21 \%$ ) featured a regular quality of life. It is noticed that the Environment domain $(48.48 \%$ ) was the only one not to reach $50 \%$.

As for the findings of WHOQOL-100 instrument facets, the results are shown in Table 2 .

According to Table 2, facets that have achieved the highest rates were: Personal relationships (74.06\%), Sexual Activity $(66.88 \%)$, Opportunity to acquire new skills $(66.56 \%)$, Spirituality/religion/personal beliefs (65\%), home ambient $(60 \%)$, social support (59.06\%) and Participation/opportunities for recreation/leisure $(56.56 \%)$.

The facets that obtained lower scores, below the range classified as regular (50\%) were: Physical environment: pollution/ noise/traffic/climate $(46.88 \%)$, Financial resources $(43.44 \%)$, 
Table 2 - Average and standard deviation of the assessed aspects, Fortaleza, Ceará, Brazil, 2013

\begin{tabular}{lll}
\hline Facet & Average & SD* \\
\hline Personal relationships & 74.06 & 2.39 \\
Sexual activity & 66.88 & 2.13 \\
Opportunities to acquire new information and skills & 66.56 & 2.60 \\
Spirituality/religion/personal beliefs & 65.00 & 3.03 \\
Home ambient & 60.00 & 1.88 \\
Social support & 59.06 & 3.03 \\
Participation/opportunities for recreation/leisure & 56.56 & 2.86 \\
Physical environment: pollution/noise/traffic/climate & 46.88 & 2.52 \\
Financial resources & 43.44 & 2.31 \\
Health and social care: availability and quality & 41.56 & 2.30 \\
Physical security and protection & 37.19 & 1.79 \\
Transport & 35.63 & 3.01 \\
Body image and appearance & 17.30 & 2.43 \\
Self-esteem & 16.41 & 2.45 \\
Work capacity & 15.35 & 3.03 \\
Thinking, learning, memory and concentration & 15.05 & 2.58 \\
Positive feelings & 15.05 & 2.50 \\
Everyday life activity & 14.70 & 2.32 \\
Energy and fatigue & 13.95 & 2.89 \\
Mobility & 13.65 & 2.74 \\
Sleep and rest & 12.85 & 3.75 \\
Pain and discomfort & 12.30 & 1.95 \\
Negative feelings & 10.15 & 3.41 \\
Medication and treatments dependency & 8.25 & 3.88 \\
\hline & &
\end{tabular}

Note: $\left(S D^{*}\right)$ - Standard deviance.

Health and Social cares: availability and quality (41.56\%) Physical security and protection $(37.19 \%)$ and Transport $(35.63 \%)$. All belonging to the $V$ domain: environment. With a poorer quality of life, it was found the medication dependency facet or treatments $(8.25 \%)$.

\section{DISCUSSION}

Health promotion is part of a new health care model that aims at the quality of life of populations, understanding it as a result of a set of determinants of socioeconomic, political, cultural and psychological context that influence society, not being restricted only to the biological field ${ }^{(6)}$. In this sense, the evaluation of the quality of life becomes an important care management tool and can help to measure and analyze the health promotion actions in progress and that ones that could be implemented in communities and health programs $\mathrm{s}^{(7)}$.

According to the latest census performed in Brazil, the percentage of people who reported having one or more of the investigated deficiencies (visual, auditory, motor and mental or intellectual) is $23.9 \%$ of the Brazilian population, which is in numbers, more than 45.6 million people, and the Northeast region with the highest concentration (over $20.1 \%$ ) $^{(4)}$.

About visual impairment, the latest census showed that it is more frequent in women and older ages. It is known that the accumulation of years of life brings numerous functional limitations that when permanent translate into deficits ${ }^{(4)}$.

In this research, visual impairment predominated in males $(80 \%)$ and people aged under $40(60 \%)$. This result can be explained by the predominant type of labor activity exercised by men and by the degree of exposure of this gender to the risk of accidents from various causes, including urban violence ${ }^{(4)}$.

Regarding income, in this study, while most claimed to have a personal income of one minimum wage, in the Brazilian census, most visually impaired was in the range of those receiving between one and two minimum salaries. As for schooling, in this research, only $5 \%$ of respondents completed higher education, while $40 \%$ declared incomplete primary education. This finding is also confirmed by the latest Brazilian census ${ }^{(4)}$.

The remuneration and schooling are directly related. People with low qualifications have difficulties to insert in the labor market and, when inserted, have low salaries. If there is a deficiency allied to a low qualification, the difficulty is greater. Even the disabled with more years of schooling are unable to enter the labor market in jobs with higher profits ${ }^{(4,8)}$.

Regarding the facet of Quality of Life of General domain, the results showed that the participants of this research are satisfied with their quality of life, getting this facet with a total score of $68.75 \%$. Featuring similar outcome with respect to the selfassessment of quality of life, in another study of 2,842 elderly visually impaired, the results showed a statistically significant difference in terms of life satisfaction, ie, subjects who obtain higher results in their perception about life satisfaction tend to get better results than the level of perceived quality of life ${ }^{(9)}$.

The Social Relations domain was highly rated by the participants, which shows that friends and family offers support and assistance ${ }^{(10)}$. This domain consists of the following facets: Personal Relationships, Sexual Activity, and Social Support. The facets with the highest quality of life index were Personal relations $(74.06 \%)$ and Sexual Activity $(66.88 \%)$.

Since the beginning of the 21th century, there is a struggle for social inclusion of minority groups, in which the visually impaired are also a part. This quest for respect provided an improvement in the social relationship between disabled and people without disabilities, but there is still prejudice on both sides, so that visually impaired people prefer to relate to people with the same condition. In this view, they have good personal relationships ${ }^{(11)}$.

Despite the Sexual Activity facet has reached good quality of life indices in this study, the literature states that the society does not realize on the disabled person the emotional and sexual bonding needs. This stigma and ignorance about the subject raise 
the chances of this group in acquiring Sexually Transmitted Diseases (STDs). Health education can be an effective measure to obtain knowledge, and thus combat social exclusion and encourage independence, self-care and healthy experience of sexuality ${ }^{(12-13)}$.

The Psychological domain is sectioned in facets Body image and appearance, Self-esteem, Negative feelings and Thinking, learning, memory, and concentration. Body image and appearance facets and Self-Esteem reached the best percentage rates. Thus, it appears that the visually impaired have a good level of satisfaction with their personal attributes. Corroborating this fact, another study showed that in general, the visually impaired are satisfied with their appearance. The result showed that no one was found ugly or unpleasant, demonstrating a high self-esteem ${ }^{(14)}$.

All participants in the current study perform some profission, and half reported having a job, and the rest said to be a student. This finding may be related to the proper percentage shown in Self-esteem facet. Factors such as access and inclusion in the labor market are considered as a way to increase self-esteem and stimulate independence of people with disabilities ${ }^{(15)}$.

The research also showed that although half of the disabled respondents be economically active and have good self-esteem, $43.44 \%$ are not satisfied with their economic situation. In socio-demographic profile, it was observed that $70 \%$ had incomes up to one minimum wage. Dissatisfaction with the economic situation was demonstrated through Financial Resources facet, which scored $43.44 \%$, below $50 \%$.

The facet that composes the Spiritual aspects, religion, personal beliefs domain obtained a good percentage (65\%). Studies suggest that spirituality and religiosity are often cited as protective factors to health and is closely related to the quality of life ${ }^{(16)}$.

When analyzing the domains, the Physical and Environment obtained the lowest scores. This finding may be associated with low levels of physical experience presented by these people, which can exacerbate physical dependence and functional capacity and thus cause losses in perceptions of quality of life and inadequate environmental conditions that still are configured as a factor that generates difficulties in the daily life of people with disabilities ${ }^{(17)}$.

In the Environment domain, the facet with the lowest score was the Transport. Corroborating this result, another study with adolescents with visual and hearing impairment, showed that the lowest average scores observed in the Environment domain, were related to the satisfaction with the means of transport, and $76.31 \%$ all adolescents claimed to be dissatisfied ${ }^{(3)}$.

This fact can be explained by the lack of accessibility and conditions of these means of transport, often not adapted and with unprepared professionals to deal with this population, generating limited mobility ${ }^{(3)}$. This is one of the major difficulties reported by visually impaired people who need help to carry over into distant, populous and unknown places ${ }^{(18)}$.

Analyzing the Independence Level domain, it is observed that this has facets with low scores. The lowest rates were Medication or treatments dependency and Mobility. This research showed that the study population has a high degree of dependence, as drug or general medical treatments. Another study affirms that people with any disability can develop greater needs and comorbidities related to medication or treatments. These comorbidities have a high potential to harm both the quality of life and health of these individuals because of their ability to aggravate the deficiency ${ }^{(19)}$.

Another problem that harms the health of the visually impaired has been shown in other research, which the majority of respondents $(63.3 \%)$ failed to learn the Braille system. Only $10 \%$ said that read and write well while $26.6 \%$ have learned little. This table reflects a serious problem regarding the safe use of medicines by studied disabled. Despite the measures being adopted by pharmaceutical companies to adapt the packaging for printing in Braille, most disabled people cannot read. Besides the difficulty in reading braille, oral drop solutions and eye drops also represent limiting the visually impaired. For them, some problems could be minimized if the packaging were different facilitating the recognition of the drug, there were a bull in audio and Braille was more readable on packaging ${ }^{(18)}$.

As for mobility, the difficulties are related to dirty sidewalks, full of holes and sunken, lack of ramps, the existence of few adapted buses and the time of traffic lights, among others. It is also possible to observe that many of the experienced difficulties are engendered in the macro-social issues, and involving the Brazilian population with or without disabilities. In Brazil, access to transportation, leisure, culture, employment is difficult for much of the population; disability, disabilities, and disadvantages arising from it, as well as the differences in opportunities, make this even more difficult to these people ${ }^{(20)}$.

Another result that drew attention to its low percentage rates was related to Negative Feelings facet, featuring a high prevalence of bad feelings among the study participants. Due to lack of knowledge, disability is still considered a burden, a problem for society and the disabled. This stigma can lead to negative feelings such as fear and low expectations for the total independence of them, believing that they will always be dependent, or that they will achieve independence only in part. Such feelings can directly affect the quality of life of these individuals ${ }^{(21)}$.

This study has limitations regarding the sample size and the fact it has been collected only in one institution since it is difficult to find them in routinely health services. Therefore, it is expected that this study will motivate further research and discussions on this topic.

However, this research indicates and features deficits of visually impaired people about this issue as an important tool to ensure effective and safe care, as well as promoting the establishment of public health policies aimed at improving the quality of life of individuals with this type deficiency.

\section{CONCLUSION}

The WHOQOL-100 allowed evaluating the quality of life of visually impaired people in a comprehensive manner.

Most facets that compose the analyzed domain in this study was score featuring satisfactory quality of life, such as: Personal relations $(74.06 \%)$, Sexual activity $(66.88 \%)$ and Spirituality/religion/personal beliefs $(65 \%)$. On the other hand, there were facets with low scores, as: Pain and discomfort (12.30\%); Negative feelings (10.15\%); Medication or treatments dependency $(8.25 \%)$, among others. 
In this context, it is important that the nurse conducts health education with the visually impaired and family to contribute to the maintenance of levels of the facets, which obtained positive results. Moreover, it should improve the low scores observed in others as: Physical Safety and Protection, Transportation, Medication and/or Treatments Dependency. Guidance and health information shall be clear and detailed for these people to become more independent in their health and well-being.

Health education should also ensure empowerment of disabled people so that they fight for urban accessibility; recreational opportunities, culture, work, education and health qualities; development and ensuring access to assistive technologies, among others. Even if guaranteed by law, access to many conquered rights remains insufficient.

\section{REFERENCES}

1. The world health organization quality of life assessment (WHOQOL): position paper from the world health organization. Soc Sci Med [Internet]. 1995[cited 2014 Apr 2];41(10):1403-9. Available from: http://www.sciencedire ct.com/science/article/pii/027795369500112K

2. Salomão SR, Mitsuhiro MRKH, Belfort Jr R. Visual impairment and blindness: an overview of prevalence and cases in Brazil. An Acad Bras Ciênc [Internet]. 2009[cited 2014 Apr 02];81(3):539-49. Available from: http://www.scielo. br/pdf/aabc/v81n3/v81n3a17.pdf

3. Interdonato GC, Greguol M. [Quality of life and physical activity in adolescents with disabilities]. Rev Bras Crescimento Desenvolv Hum [Internet]. 2011[cited 2014 Apr 2];21(2):282-95. Available from: http://pepsic.bvsalud. org/pdf/rbcdh/v21n2/11.pdf Portuguese.

4. Baptista EA, Rigotti JIR. Minas Gerais e sua população de deficientes: um estudo a partir dos censos demográficos de 2000 e 2010. Caderno de Geografia [Internet]. 2014[cited 2014 Apr 02];24(41):98-118. Available from: http://periodicos.pucminas.br/index.php/geografia/ article/viewFile/P.23182962.2014v24n41p98/6022

5. Pedroso B, Pillati LA, Reis DR. Cálculo dos escores e estatística descritiva do WHOQOL-100 utilizando o Microsoft Excel. Rev Bras Qual Vida [Internet]. 2009 [cited 2014 Apr 2];1(1):23-32. Available from: http://revistas.utfpr. edu.br/pg/index.php/rbqv/article/view/366

6. Tesser CD, Garcia AV, Argenta CE, Vendruscolo C. Concepções de promoção da saúde que permeiam o ideário de equipes de Estratégia de Saúde da Família da Grande Florianópolis. R Saúde Públ Santa Cat [Internet]. 2010[cited 2014 Apr 2];3(1):42-56. Available from: http://esp. saude.sc.gov.br/sistemas/revista/index.php/inicio/article/ viewFile/68/111

7. Castro DFA, Fracolli LA. Qualidade de vida e promoção da saúde: em foco as gestantes. O Mundo da Saúde [Internet]. 2013[cited 2014 Apr 2];37(2):159-65. Available from: http://www.saocamilo-sp.br/pdf/mundo_saude/102/4.pdf

8. Pereira ACC, Passerino L. Um estudo sobre o perfil dos empregados com deficiência em uma organização. Rev Bras Educ Espec [Internet]. 2012[cited 2014 Apr 2];18(2):24564. Available from: http://www.scielo.br/pdf/rbee/v18n2/ v18n2a06.pdf

9. La Grow S, Alpass F, Stephens C, Towers A. Factors affecting perceived quality of life of older persons with self-reported visual disability. Quality of Life Research [Internet]. 2011[cited 2014 Apr 2];20(3):407-13. Available from: http://link.springer. com/article/10.1007\%2Fs11136-010-9758-6\#
10. Xavier FIS, Silva CA, Gil FE, Vieira BNN, Queiroga SR. Quality of life of adults with spinal cord injury: a study using the WHOQOL-bref. Rev Esc Enferm USP [Internet]. [cited 2014 Apr 2];45(6):1361-8. Available from: http:// www.scielo.br/pdf/reeusp/v45n6/en_v45n6a13.pdf

11. Franco JR, Denari FE. A Sociedade e a Cegueira: discriminação e exclusão. Benjamin Constant [Internet]. 2011[cited 2014 May 2];48(1). Available from: http://www.ibc. gov.br/revistabenjaminconstant/index.php/b3njc0nst/ article/view/1/38

12. Wanderley LD, Barbosa GOL, Rebouças CBA, Oliveira PMP, Pagliuca LMF. Sexualidade, DST e preservativo: comparativo de gênero entre deficientes visuais. Rev Enferm UERJ [Internet]. 2012[cited 2014 Apr 02];20(4):463-9. Available from: http://www.facenf.uerj.br/v20n4/v20n4a09.pdf

13. Sales AS, Oliveira RB, Araújo EM. Inclusão da pessoa com deficiência em um Centro de Referência em DST/AIDS de um município baiano. Rev Bras Enferm [Internet]. 2013[cited 2014 Aug 2];66(2):208-14. Availablefrom: http://www.scielo. br/pdf/reben/v66n2/09.pdf

14. Interdonato GC, Greguol M. Autoanálise da imagem corporal de adolescentes com deficiência visual sedentários e fisicamente ativos. Conexões: Rev Fac Educ Fís [Internet]. 2009 [cited 2014 May 2];7(3):1-13. Available from: http://fefnet178.fef.unicamp.br/ojs/index.php/fef/article/ view/454/324

15. Mattevi BS, Bredemeier J, Fam C, Fleck MP. Quality of care, quality of life, and attitudes toward disabilities: perspectives from a qualitative focus group study in Porto Alegre, Brazil. Rev Panam Salud Pública [Internet]. 2012[cited 2014 May 2];31(3):188-96. Available from: http://www.scielosp.org/pdf/rpsp/v31n3/02.pdf

16. Panzini RG, Maganha C, Rocha NS, Bandeira DR, Fleck MP. Validação brasileira do Instrumento de Qualidade de Vida/ espiritualidade, religião e crenças pessoais. Rev Saúde Pública [Internet]. 2011[cited 2014 Apr 2];45(1):153-65. Available from: http://www.scielo.br/pdf/rsp/v45n1/1765.pdf

17. Lima RMC, Ribeiro PRQ, Tonello MGM. Percepção da qualidade de vida por pessoas com deficiências físicas praticantes e não praticantes de atividades de lazer. Licere [Internet]. 2012[cited 2014 Apr 2];15(4):1-14. Available from: http:// www.anima.eefd.ufrj.br/licere/pdf/licereV15N04_a8.pdf

18. Nascimento EL, Marques LAM. O Deficiente Visual e a Atenção Farmacêutica. Lat Am J Pharm [Internet]. 2009[cited 2014 Apr 2];28(2):203-10. Available from: http://www. unifal-mg.edu.br/gpaf/files/file/deficiente\% 20visual.pdf

19. Castro SS, Pelicioni AF, Cesar CLG, Carandina L, Barros 
MBA, Alves MCGP, Goldbaum M. Use of medicines by persons with disabilities in São Paulo state areas, Southeastern Brazil. Rev Saúde Pública [Internet]. 2010[cited 2014 Apr 2];44(4):1-9. Available from: http://www.scielo. $\mathrm{br} / \mathrm{pdf} / \mathrm{rsp} / \mathrm{v} 44 \mathrm{n} 4 / \mathrm{en} \_03 . p d f$

20. Othero MB, Ayres JRCM. Necessidades de saúde da pessoa com deficiência: a perspectiva dos sujeitos por meio de histórias de vida. Interface (Botucatu) [Internet]. 2012[cited 2014 Apr 2]; 16(40):219-33. Available from: http://www.scielo.br/pdf/icse/v16n40/aop1212.pdf

21. Chacon MCM. Aspectos relacionais, familiares e sociais da relação pai-filho com deficiência física. Rev Bras Educ Espec [Internet]. 2011[cited 2014 Apr 2];17(3):441-58. Available from: http://www.scielo.br/pdf/rbee/v17n3/v17n3a07.pdf 